\title{
Density and Richness of Benthic Invertebrate Populations in the North Sydenham River of Southwestern Ontario (1996-2000) Compared with Those of the St. Clair River (1990-1995)
}

\author{
I. W. E. HARris ${ }^{1}$, C. F. DrURY ${ }^{2}$, R. R. SimARD ${ }^{3}$, and T. Q. ZHANG ${ }^{2}$ \\ ${ }^{1} 1310$ Hillcrest Drive, Sarnia, Ontario N7S 2N4 Canada \\ ${ }^{2}$ Greenhouse and Processing Crops Research Centre, Agriculture and Agri-Food Canada, Harrow, Ontario N0R 1G0 Canada \\ ${ }^{3}$ Soils and Crops Research and Development Centre, Agriculture and Agri-Food Canada, Ste. Foy, Québec G1V 2J3 Canada
}

Harris, I. W. E., C. F. Drury, R. R. Simard, and T. Q. Zhang. 2003. Density and richness of benthic invertebrate populations in the North Sydenham River of Southwestern Ontario (1996-2000) compared with those of the St. Clair River (19901995). Canadian Field-Naturalist 117(2): 267-277.

Richness (the number of invertebrate families/sample site) and density (the number of invertebrates/sq $\mathrm{m}$ ) of benthic populations in the North Sydenham River were measured and compared with similar estimates for the St. Clair River. Seventeen sample sites were examined from May to October over five consecutive years. At each sample site, particle size distribution of the sediment, sediment temperature, total phosphorous, total nitrogen, total carbon, and water flow rate were measured. Physical and chemical characteristics of the North Sydenham system over the $100 \mathrm{~km}$ run examined were less variable than those of the St. Clair. Statistically significant but weak multiple linear correlations were found for richness and density with several of the measured variables. Invertebrate populations in the North Sydenham River were less rich and less dense than those in the downstream reach of the St. Clair and exhibited a different distribution of abundance among the orders of organisms. As in the St. Clair River, some evidence of long term cycling of abundance in several families of invertebrates was found in the North Sydenham.

Key Words: benthic invertebrates, richness, density, North Sydenham River, Southwestern Ontario, sediments, nitrogen, phosphorous, organic debris, St. Clair River.

In 1996 a five-year study was undertaken to identify some major variables correlating with the richness and density of invertebrate populations in the sediments of the North Sydenham River in Southwestern Ontario. This work should be viewed as complementary to the similar study of invertebrates in the St. Clair River for the 1990-1995 period (Harris 1999). The comparison of the populations in these two streams will provide base-line data for assessing the effectiveness of remedial actions underway in the Sydenham River system (Whitford 2001*) and in the St. Clair as required by the International Joint Commission (I.J.C.) Great Lakes Water Quality Agreement (1987*). Furthermore, comparable invertebrate data for streams of such widely differing characteristics will assist in the interpretation of the effects of physical and chemical variables on invertebrate populations in other river systems (Statzner and Higler 1986; Meyer 1990). Although a few studies focussed on Bivalvia have been reported for the Sydenham River System as a whole (Mackie and Topping 1988; Clarke 1992; VanDerWal $2001 *$ ), no comprehensive studies of the invertebrate population in the North Sydenham branch have been published.

\section{Study Site}

The North Sydenham River is the major northern branch of the Sydenham River in Southwestern Ontario, flowing northeast-southwest and entering the main stream at the town of Wallaceburg. The Sydenham
River then continues south-westerly to the Chenal Ecarte, the eastern channel in the delta of the St. Clair River in Lake St. Clair (Figure 1).

The North Sydenham is a third order stream flowing through agricultural land which supports crops of soybeans, corn, hay and various grains as well as cattle, hogs and poultry. In some sections deciduous trees and brush overhang the stream. The stream bed is a glacial clay and with the variable flows resulting from periodic heavy rains, field-tile drainage, and cattle access, the water carries suspended solids varying between $125 \mathrm{mg} / \mathrm{l}$ in the lower reach to $55 \mathrm{mg} / \mathrm{l}$ in the upper portions of the system (Chambers 1997*). Comparable data for the shoreline stream of the St. Clair River are normally in the range $1-10 \mathrm{mg} / \mathrm{l}$ with one to three periods per year with values as high as $30 \mathrm{mg} / \mathrm{l}$ for a week or two following storms on Lake Huron (Frais 2002*). The water in the North Sydenham is opaque at depths of more than about one centimetre and turbidity has been reported in the range 50-75 Jackson Turbidity Units (Whitford 2001*). The nearshore water of the St. Clair River is clear most of the time and the bottom can be seen at depths up to three metres. The course of the North Sydenham is sufficiently convoluted that about 100 kilometres is required to traverse a straight line distance of about 50 kilometres. The overall bed gradient is 0.0003 .

In the lower reaches of the North Sydenham River, historical data show that flow is normally in the range of six to sixteen cubic metres per second during the 
summer months (McDougall 1998*), occasionally reaching thirty cubic meters per second in the early spring. The Bear Creek/Durham Creek tributary system contributes about twenty percent of this flow and the Black Creek/Fox Creek tributary contributes about seventy percent. Several small tributaries account for the remainder. In the latter half of the summer, at distances more than sixty kilometres upstream, flow is negligible, and the stream becomes a series of long narrow ponds most of the time.

Historical data (McDougall 1998*) for the North Sydenham River show a peak water temperature of about $24^{\circ} \mathrm{C}$ at the end of June (weeks 26-27). Comparable data for the St. Clair River (Kuley and Brooks $2001^{*}$ ) show a peak at about $22^{\circ} \mathrm{C}$ in mid-August (weeks 32-33). Sediment temperatures were not measured in the St. Clair River study.

\section{Materials and Methods}

Twelve parameters were considered to be independent variables having the potential to be correlated at a statistically significant level with the richness and density of invertebrate populations in the river as follows: year five years between 1996 and 2000 including (96, $97,98,99,100)$.

weekno sampling week (weeks numbered from the first week in January of each year).

riverkm nominal stream distance in kilometres measured upstream of the base point at the junction of the North Sydenham River with the main flow at Wallaceburg.

ms river surface flow rate at the time and point of sampling (metres/sec).

vg gravel content of sediment sample - volume percent of inorganic material having a particle size $>2.0 \mathrm{~mm}$.

vs sand content of sediment sample - volume percent of inorganic material having a particle size between $2.0 \mathrm{~mm}$ and $0.2 \mathrm{~mm}$.

vm mud content of sediment sample - volume percent of inorganic material having a particle size $<0.2 \mathrm{~mm}$.

vv vegetation content of sediment sample - volume percent of macrophytic material on the $2 \mathrm{~mm}$ screen.

pugg total phosphorous content of sediment expressed as micrograms/gram.

nugg total nitrogen content of sediment expressed as micrograms/gram.

cugg total carbon content of sediment expressed as micrograms/gram.

sedtc temperature of sediment at the point and time of sampling expressed as degrees Celsius.

Total carbon content (cugg) and sediment temperature (sedtc) were not measured in the St. Clair River study (Harris 1999). The volume percent variables are obviously interrelated since they must sum to one hundred. However, the analysis of the data by multiple linear regression identifies the classes of sediment particle size which are statistically significant in the correlations. The dependent variables in the analysis of the data were:

richness number of invertebrate families found at each site. density total of invertebrate individuals found at each site expressed as number $\mathrm{m}^{2}$.

Seventeen sample points were established along the lower section of the river, Bear Creek, Durham Creek, Fox Creek, and Black Creek as shown in Figure 1. For ease of sampling and to minimize the risk of contamination by storm drainage, all were located about $20 \mathrm{~m}$ upstream of road bridges over the streams. The geographic coordinates for all sample points are listed in Table 1. Only that part of the North Sydenham system lying within the Townships of Enniskillen, Plympton, Moore, and Sombra of the County of Lambton was included in this study. Nine of the 17 sampling sites in this study were located adjacent to cultivated fields or pasture; the remainder were bordered with willow brush and/or deciduous trees.

Samples were taken at a depth of $1 \mathrm{~m}$ about $2 \mathrm{~m}$ from the shore or in midstream in the upper reaches where the stream was shallow and narrow. Each site was sampled once each year between May and October for the period 1996 through 2000. As illustrated in Figure 2, a schedule was established to ensure that samples were taken during the five-year study at each site over as wide a seasonal range as possible with a minimum of duplication.

Sampling for invertebrate identification at each site consisted of three grabs with a Petit Ponar dredge $\left(0.0234 \mathrm{~m}^{2}\right)$ the contents of which were combined, washed on a screen with $0.5 \mathrm{~mm}$ mesh, and preserved in $2 \%$ formaldehyde. The invertebrates present were subsequently separated by hand under magnification from the sediment debris, identified to the family level, counted and preserved in 70\% isopropanol containing $0.2 \%$ glycerin. Empty shells and exuviae were not counted. Identification of invertebrates followed keys published by Merritt and Cummins (1988), Pennak (1989), Peckarsky et al. (1990) and Thorp and Covich (1991).

An archive of all specimens found, in vials coded with invertebrate order, sample site, and sampling date was accumulated to allow verification of invertebrate identification and counts. All these specimens have been deposited in the Zoology Department of the University of Western Ontario (Robert Bailey).

At each sampling, a fourth grab of sediment was taken to characterize the distribution of particle sizes in the sediment. Following consultation with the Geology Department at the University of Western Ontario, an arbitrary decision was made to use screens with openings of $2 \mathrm{~mm}$ and $0.2 \mathrm{~mm}$ and a graduated cylinder to measure the volume percent of gravel, sand and mud respectively. When present, the volume percent of macrophytic debris was estimated visually from the residue on the $2 \mathrm{~mm}$ screen and the volume percent gravel corrected accordingly. 


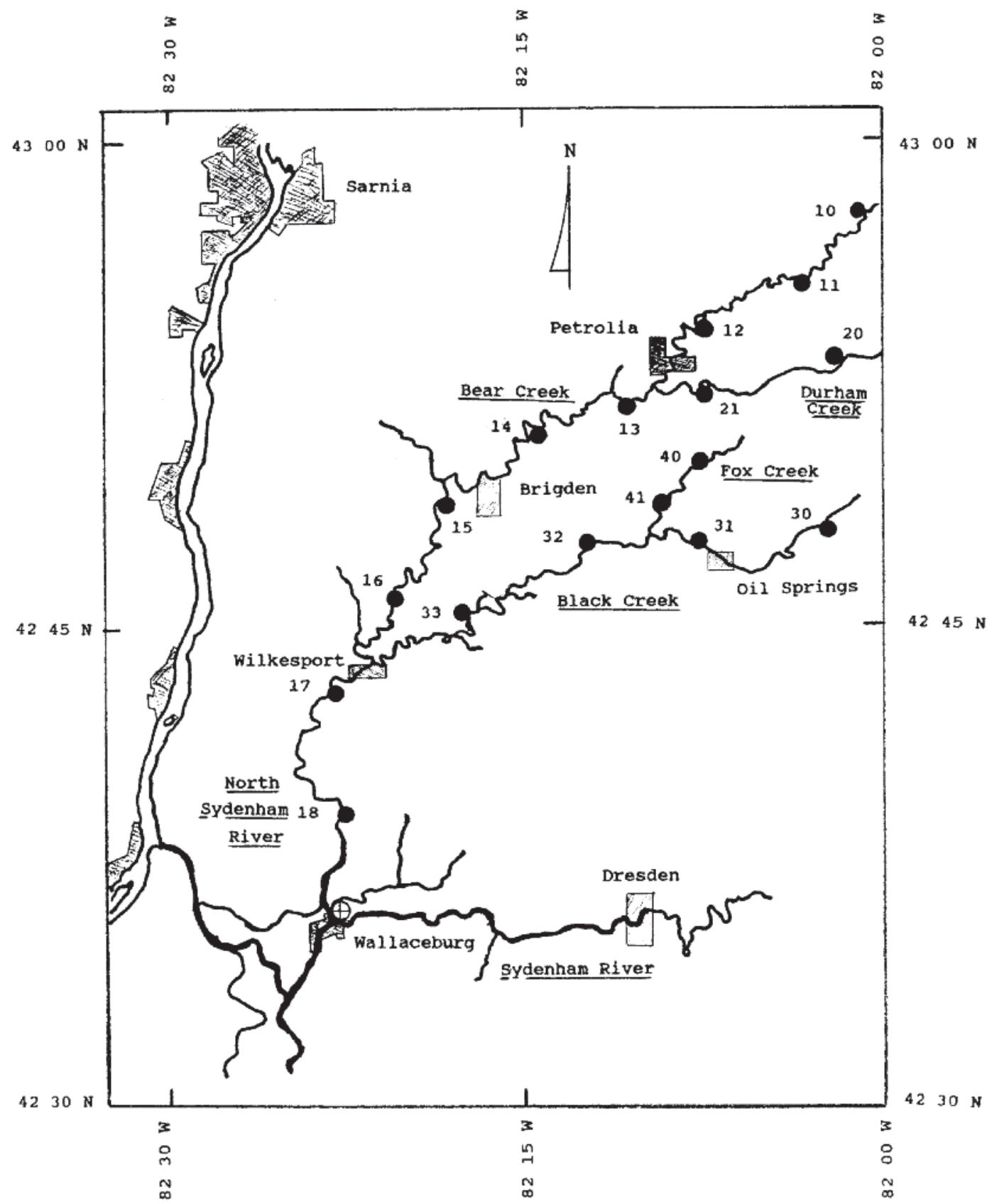

FIgURE 1. The North Sydenham River system and the adjacent St. Clair River showing the location of the sampling points (numbered).

A fifth grab sample of sediment was taken at each sampling for analysis for total nitrogen, total phosphorous and total carbon. The analyses were performed in the laboratories of Agriculture and Agri-Food Canada at Harrow, Ontario and Ste. Foy, Quebec.
Current velocity (metres/sec) at the surface was measured by timing the passage of a wooden float over a fixed distance. Sediment temperature was measured by probing the stream bottom with a thermometer to a depth of about $5 \mathrm{~cm}$. 
TABLE 1. Coordinates for stream monitoring sites.

\begin{tabular}{|c|c|c|c|c|c|c|c|c|}
\hline \multirow{2}{*}{$\begin{array}{l}\text { Site } \\
\text { Name }\end{array}$} & \multirow{2}{*}{$\begin{array}{c}\text { Site } \\
\text { Number }\end{array}$} & \multirow{2}{*}{$\begin{array}{c}\text { Nominal } \\
\text { River } \\
\text { Km } \\
*\end{array}$} & \multicolumn{3}{|c|}{ Latitude(N) } & \multicolumn{3}{|c|}{ Longitude(W) } \\
\hline & & & Deg. & $\begin{array}{c}\text { Min. } \\
+\end{array}$ & Sec. & Deg. & $\underset{+}{\text { Min. }}$ & Sec \\
\hline \multicolumn{9}{|c|}{ BEAR CREEK/DURHAM CREEK TRIBUTARIES: } \\
\hline Bear Creek & 10 & 106.5 & 42 & 57 & 20 & 82 & 0 & 40 \\
\hline Bear Creek & 11 & 96.7 & 42 & 55 & 25 & 82 & 3 & 0 \\
\hline Bear Creek & 12 & 84.8 & 42 & 53 & 50 & 82 & 7 & 30 \\
\hline Bear Creek & 13 & 72.4 & 42 & 51 & 50 & 82 & 11 & 0 \\
\hline Bear Creek & 14 & 59.4 & 42 & 51 & 0 & 82 & 14 & 30 \\
\hline Bear Creek & 15 & 45.7 & 42 & 48 & 50 & 82 & 18 & 0 \\
\hline Bear Creek & 16 & 34.4 & 42 & 45 & 40 & 82 & 20 & 50 \\
\hline Durham Creek & 20 & 95.9 & 42 & 52 & 50 & 82 & 1 & 10 \\
\hline Durham Creek & 21 & 80.1 & 42 & 51 & 50 & 82 & 7 & 40 \\
\hline \multicolumn{9}{|c|}{ BLACK CREEK/FOX CREEK TRIBUTARIES: } \\
\hline Black Creek & 30 & 77.2 & 42 & 47 & 50 & 82 & 2 & 0 \\
\hline Black Creek & 31 & 64.8 & 42 & 47 & 20 & 82 & 8 & 20 \\
\hline Black Creek & 32 & 53.7 & 42 & 47 & 10 & 82 & 12 & 0 \\
\hline Black Creek & 33 & 40.0 & 42 & 45 & 10 & 82 & 17 & 0 \\
\hline Fox Creek & 40 & 69.2 & 42 & 49 & 40 & 82 & 8 & 20 \\
\hline Fox Creek & 41 & 63.8 & 42 & 48 & 30 & 82 & 7 & 30 \\
\hline \multicolumn{9}{|c|}{ NORTH SYDENHAM: } \\
\hline North Sydenham & 17 & 20.3 & 42 & 42 & 40 & 82 & 22 & 40 \\
\hline North Sydenham & 18 & 7.8 & 42 & 39 & 0 & 82 & 22 & 30 \\
\hline
\end{tabular}

* distance measured upstream from Wallaceburg

+ maps published by Energy Mines and Resources Canada.1987. Maps number 40-J/9, 40-J/10, 40-J/16, 40-O/1.

The data were analysed using software developed by the Centers for Disease Control and Prevention (CDC) in Atlanta, Georgia, USA (titled EpiInfo, Version 6). A diskette containing the entire database can be obtained from the author at no charge. If required, the data base can be reformatted for several other commercial software systems.

\section{Results and Discussion}

To simplify the presentation of the findings of this study, data for the two tributary systems of the North Sydenham River have been grouped and recorded in Table 2 as arithmetic means with associated statistical characteristics. Also recorded for comparison are data for the downstream reach of the St. Clair River (Harris 1999). Significance of the difference between many of these means is indeterminate because of significant differences between the variances. However, some observations of interest are as follows:

(i) at the 95\% level of confidence, the lower reach of the North Sydenham River shows a higher population density than the Bear Creek/Durham Creek tributary system but is not significantly different from the downstream reach of the St. Clair River. The significance of the difference for the Black Creek/Fox Creek system is indeterminate because of the difference of variances. (ii) the lower reach of the North Sydenham River shows a significantly higher richness than both tributary systems.

(iii) mean sediment temperatures of all reaches of the North Sydenham system do not differ. As with the water, the sediment temperature profile is parabolic during the summer months. However, the maximum occurs at about $22^{\circ} \mathrm{C}$ in mid-July (weeks 28-30), about two degrees lower and two weeks later than the water temperature (McDougall 1998*).

(iv) the sediment of the Black Creek/Fox Creek tributary system has a higher proportion of gravel than either the Bear Creek/Durham Creek system or the downstream main portion of the river. These differences are significant at the $95 \%$ level of confidence. The gravel content for all three appears to be higher than for the downstream reach of the St. Clair but the statistical significance of that difference is indeterminate because of variance differences.

(v) the sand content of the sediment throughout the North Sydenham River is the same and about half that in the downstream reach of the St. Clair but the statistical significance of the latter difference is indeterminate.

(vi) the proportion of mud in all sediments is the same.

(vii) the proportion of gross organic debris in the Black Creek/Fox Creek system is lower than in either of the other two segments of the river at the $95 \%$ level of confidence. 


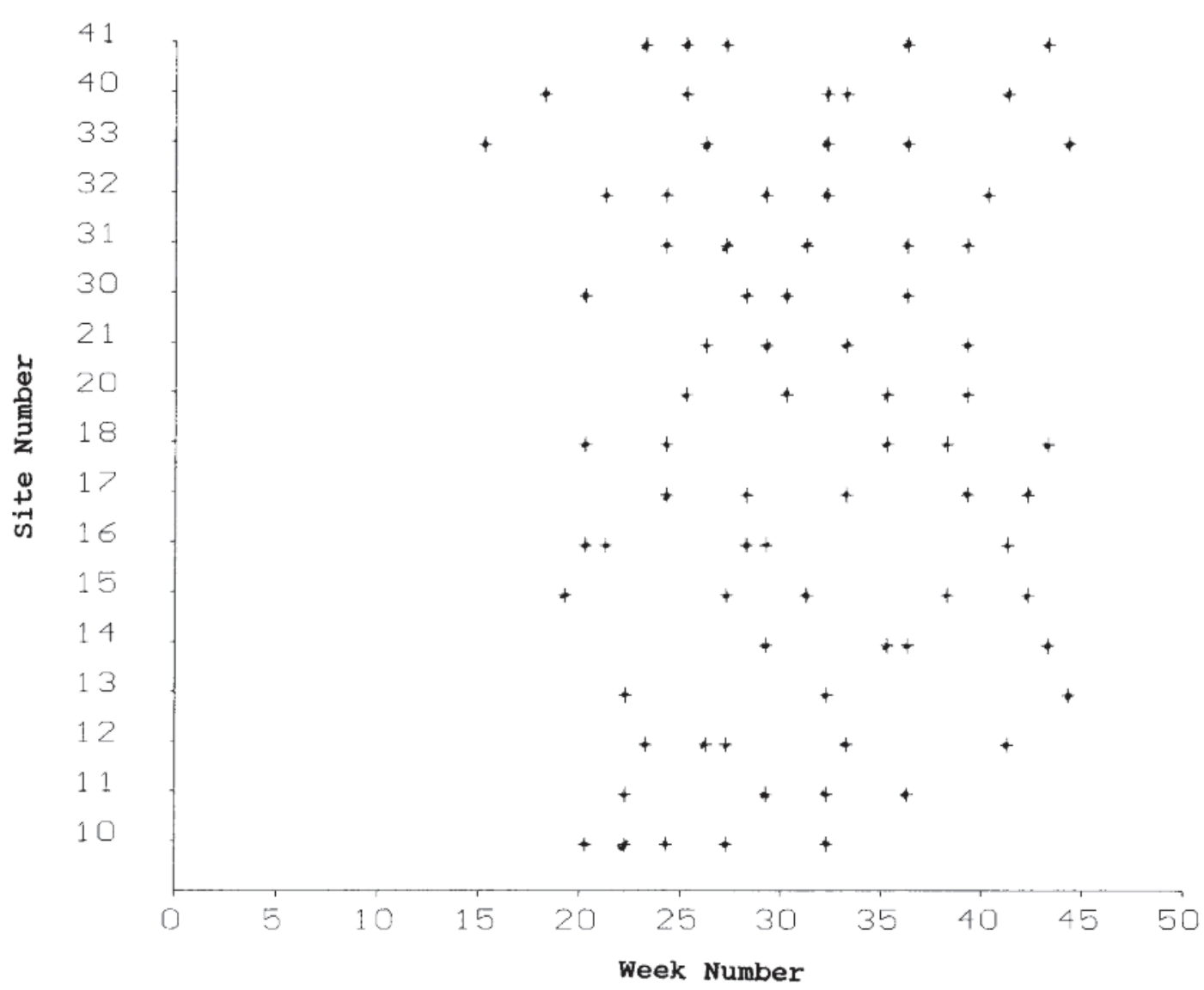

FIGURE 2. The sampling schedule for the period 1996-2000.

(viii) the phosphorous content of the sediments throughout the North Sydenham River is the same and about twice that in the lower St. Clair River. However, the $\mathrm{N} / \mathrm{P}$ ratios of the sediments in both systems are in the range of 2.5 to 3.0. The N/P ratio of the water in the North Sydenham has been found to be about 8 (Chambers 1997*).

(ix) the Black Creek/Fox Creek tributary system sediments contain levels of nitrogen lower, at $95 \%$ confidence, than the other two segments of the system but the nitrogen level in the downstream reach of the St. Clair River is lower still.

(x) the sediment in the Bear Creek/Durham Creek tributary system contains significantly more carbon than the other two parts of the river. The $\mathrm{C} / \mathrm{N}$ ratio in the North Sydenham system as a whole is in the range 30 to 35 .

The higher values of density and richness in the downstream reach of the North Sydenham River relative to the tributary systems and the absence of a consistent pattern of values in the other stream characteristics indicate that none of the measured variables exert a major influence on either richness or density of inver- tebrate populations. This observation is reinforced when the data for the St. Clair River are considered as well.

The mean values for richness, recorded in Figure 3 which decline with passage upstream, follow the normal pattern observed in numerous stream studies (Waters 1972; Williams 1981) as well as the recent study on the St. Clair River (Harris 1999).

The data in Figure 4 for population density show little evidence of a trend with passage upstream in contrast to the marked decline observed in the upper reach of the St. Clair River.

Error bars have been omitted from Figures 3, 4, and 5 because they would include variation of all the measured variables except river distance and would therefore be misleading. Further, the figures would be very difficult to read. These figures are presented to illustrate trends rather than precision.

To examine further the significance of the independent variables on richness and density, multivariate linear regressions (Draper and Smith 1991) were run repeatedly for both using all data from all sites for 
TABLE 2. Arithmetic means of basic river characteristics and corresponding density and richness of benthic invertebrate populations in the North Sydenham River and the downstream reach of the St. Clair River (Harris 1999).

\begin{tabular}{|c|c|c|c|c|c|c|c|c|c|}
\hline \multirow{2}{*}{$\begin{array}{l}\text { Density } \\
\text { (org.m }{ }^{2}\end{array}$} & \multirow{2}{*}{$\begin{array}{l}\text { Richness } \\
\text { (fam./site) } \\
*\end{array}$} & \multirow{2}{*}{$\begin{array}{l}\text { Sediment } \\
\text { Temp. (C) }\end{array}$} & \multicolumn{4}{|c|}{ Sediment Character } & \multicolumn{2}{|c|}{ Nutrient } & Carbon \\
\hline & & & $\begin{array}{l}\mathrm{vg} \\
*\end{array}$ & $\begin{array}{l}\text { VS } \\
*\end{array}$ & $\begin{array}{c}\mathrm{vm} \\
*\end{array}$ & $\begin{array}{l}\text { VV } \\
*\end{array}$ & $\begin{array}{c}\text { pug } \\
*\end{array}$ & $\begin{array}{c}\text { nugg } \\
*\end{array}$ & \\
\hline
\end{tabular}

Bear Creek/Durham Creek Tribuaries (Siteno 10-16,20,21):

$\begin{array}{lcccccccccc}\text { Mean } & 2447.8 & 9.7 & 19.0 & 15.0 & 24.0 & 43.0 & 17.9 & 590.8 & 1453.7 & 48423 \\ & & 42 & 42 & 42 & 42 & 42 & 42 & 42 & 42 & 42 \\ \text { Observations (n) } & 419.1 & 0.5 & 0.5 & 2.8 & 2.6 & 4.4 & 3.3 & 18.4 & 124.2 & 2045 \\ \text { Standard Error } & 7.4 \mathrm{E}+6 & 9.6 & 11.1 & 317.6 & 282.6 & 831.6 & 452.8 & 1.4 \mathrm{E}+4 & 0.6 \mathrm{E}+6 & 1.8 \mathrm{E}+8 \\ \text { Variance } & & & & & \end{array}$

Black Creek/Fox Creek Tributaries (Siteno 30-33,40,41):

\begin{tabular}{|c|c|c|c|c|c|c|c|c|c|c|}
\hline Mean & 2408.1 & 10.8 & 18.9 & 23.8 & 20.4 & 46.0 & 9.9 & 554.9 & 1170.8 & 41107 \\
\hline Observations (n) & 29 & 29 & 29 & 29 & 29 & 29 & 29 & 29 & 29 & 29 \\
\hline Standard Error & 299.7 & 0.7 & 0.6 & 3.3 & 2.5 & 4.2 & 3.3 & 16.8 & 93.2 & 2200 \\
\hline Variance & $2.6 \mathrm{E}+6$ & 15.9 & 10.7 & 321.8 & 176.3 & 508.1 & 311.8 & $0.8 \mathrm{E}+4$ & $0.2 \mathrm{E}+6$ & $1.4 \mathrm{E}+8$ \\
\hline
\end{tabular}

North Sydenham River (Siteno 17,18):

$\begin{array}{lcccccccccc}\text { Mean } & 4796.8 & 14.2 & 19.6 & 13.7 & 21.4 & 46.7 & 18.4 & 582.0 & 1475.6 & 43640 \\ & & 10 & 10 & 10 & 10 & 10 & 10 & 10 & 10 & 10 \\ \text { Observations (n) } & 797.3 & 0.7 & 1.0 & 4.6 & 3.3 & 7.0 & 6.2 & 52.4 & 289.3 & 2736 \\ \text { Standard Error } & 6.4 \mathrm{E}+6 & 5.5 & 10.0 & 208.4 & 112.5 & 489.8 & 378.9 & 2.7 \mathrm{E}+4 & 0.8 \mathrm{E}+6 & 0.7 \mathrm{E}+8 \\ \text { Variance } & & & & & & \end{array}$

\section{St. Clair River (Siteno 009,010,106,107,108):}

\begin{tabular}{lccccccccccc} 
Mean & 5067.4 & 18.9 & - & 4.5 & 41.0 & 42.4 & 11.9 & 291.1 & 812.7 & - \\
Observations (n) & 21 & 21 & - & 21 & 21 & 21 & 21 & 21 & 21 & - \\
Standard Error & 577.0 & 1.2 & - & 1.1 & 5.7 & 6.4 & 2.5 & 15.6 & 75.3 & - \\
Variance & $7.0 \mathrm{E}+6$ & 32.2 & - & 25.5 & 686.9 & 856.8 & 132.5 & $0.5 \mathrm{E}+4$ & $0.1 \mathrm{E}+6$ & - \\
\hline \hline
\end{tabular}

* abbreviations defined in Materials and Methods section

the entire five-year period. Initially in each case, all independent variables were included in the calculation. In successive runs, the independent variable with least significance was eliminated until only those with B coefficients significant at the $95 \%$ level remained. The numerical data for the final correlations are recorded in Table 3. Richness and density in both arithmetic and $\log$ form were run to assess the effect of the marked positive skewness of these data. The final correlation for density in arithmetic form did not reach significance at the $95 \%$ level of confidence. The procedure here is the same as that used in the St. Clair River study.

This analysis revealed the following equations to be significant at the $95 \%$ level:

$$
\begin{aligned}
\text { Richness }= & 12.9+0.561(\mathrm{vv})+0.007(\mathrm{pugg}) \\
& -0.048(\text { riverkm })-0.210(\text { sedtc }) \\
& \text { Correlation coefficient }\left(\mathrm{r}^{\wedge} 2\right)=0.36 \\
& \\
\log (\text { Richness })= & 0.78+0.003(\mathrm{vv})+0.0003(\text { pugg }) \\
& -0.002(\text { riverkm })+0.004(\text { weekno }) \\
& \text { Correlation coefficient }\left(\mathrm{r}^{\wedge} 2\right)=0.32
\end{aligned}
$$

$\log ($ Density $)=2.72+0.005(\mathrm{vv})+0.015($ weekno $)$ Correlation coefficient $\left(\mathrm{r}^{\wedge} 2\right)=0.10$
All these correlations, although statistically significant at the $95 \%$ level, are weak in that they account for only a small proportion of the total variation in the richness and density observed. The corresponding correlations found in the St. Clair River study (Harris 1999) were much more robust, being in the range of 40\%-60\%. Apparently, variables other than those measured are influential; perhaps for example, water clarity or the daily temperature variation.

The weakness of these correlations is also attributable in part to the narrower ranges in the measured independent variables in the North Sydenham compared to those in the St. Clair River. Except for the amounts of coarse vegetation debris (vv) and the longer upstream distance (riverkm), the ranges for the independent variables in the North Sydenham are about half those observed in the St. Clair River. In other words, the North Sydenham River is a much more homogeneous environment than the St. Clair.

It should be emphasised that these are correlations and not necessarily demonstrations of cause and effect. For example, the positive effect of the presence of coarse vegetation debris on both richness and density 


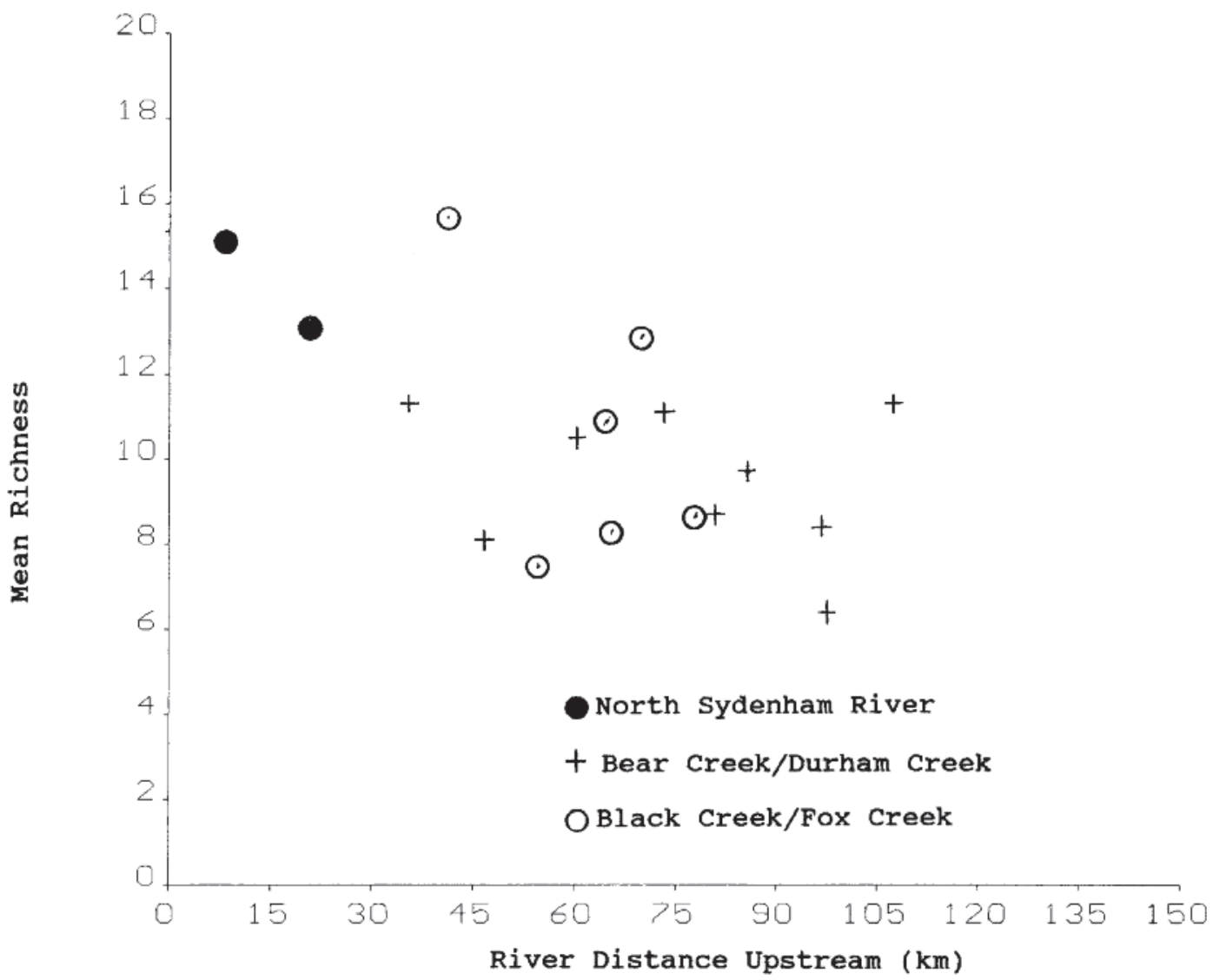

FIGURE 3. Mean richness (number of invertebrate families/site) plotted against distance upstream (km).

could be either that it provides cover for invertebrates from predators, that it provides nutrient, or that the presence of overhanging trees and brush provides a more undisturbed stream bed.

Nevertheless, richness is shown to be favoured by the presence of coarse vegetation debris, higher levels of phosphorous, lower sediment temperatures, and by sampling farther downstream later in the year.

Density tends to be increased by sampling later in the year at sites where coarse vegetation debris is present. The presence of such material is known to provide refuge and nutrients for invertebrates (Dudley and Anderson 1982). The negative association with coarse vegetation found in the St. Clair River study remains anomalous.

It should be noted here that the coarse vegetation debris found in the North Sydenham River is very different from that found in the St. Clair. In the North Sydenham it is composed of leaf litter and decaying wood. In the St. Clair, when present, it is mainly growing macrophytes (Chara spp. and Potamogeton spp.).

In contrast to the findings in the St. Clair River study, richness in the North Sydenham exhibited no yearly trend. No yearly trend in density was observed in either river system.

Evidence for cycling in the abundance of some invertebrate families observed in the study of the St. Clair was also found in the North Sydenham study. Table 4 records this evidence. A comparison with the comparable data from the St. Clair River study (Harris 1999) suggests that the more lentic environment of the North Sydenham supports a more constant invertebrate population exhibiting cycles of density having smaller amplitude and longer periods. The population in a pond environment would therefore be expected to exhibit cycles with even smaller amplitude and longer periods. The evidence for long term cyclic variation in the density of some invertebrate families suggests that studies of the abundance of invertebrate populations in a river system or pond must be conducted over a consecutive period of years if the results are to be credible.

The abundance of individuals in the various orders of invertebrates found in the North Sydenham River compared to the St. Clair River is recorded in Table 5. 
TABLE 3. Regression analyses for richness and density.

\begin{tabular}{|c|c|c|c|c|c|c|}
\hline \multicolumn{7}{|c|}{$\begin{array}{c}\text { RICHNESS } \\
\text { Correlation coefficient: } \mathrm{r}^{\wedge} 2=0.36\end{array}$} \\
\hline Variable & Mean & $\begin{array}{c}\text { B } \\
\text { coefficient }\end{array}$ & Lower & $\begin{array}{l}\text { 95\% confidence } \\
\text { Upper }\end{array}$ & Std Error & $\begin{array}{l}\text { Partial } \\
\text { F-test }\end{array}$ \\
\hline VV & 15.11 & 0.0561 & 0.021 & 0.091 & 0.018 & 10.28 \\
\hline PUGG & 576.86 & 0.0067 & 0.001 & 0.013 & 0.003 & 5.14 \\
\hline RIVERKM & 61.99 & -0.0480 & -0.074 & -0.022 & 0.013 & 13.76 \\
\hline SEDTC & 18.89 & -0.2102 & -0.419 & -0.001 & 0.105 & 4.02 \\
\hline Y-Intercept & 12.871 & & & & & \\
\hline \multicolumn{7}{|c|}{$\begin{array}{c}\text { LOG (RICHNESS) } \\
\text { Correlation coefficient: } \mathrm{r}^{\wedge} 2=0.32\end{array}$} \\
\hline Variable & Mean & $\frac{\text { B }}{\text { coefficient }}$ & Lower & $\begin{array}{l}95 \% \text { confidence } \\
\text { Upper }\end{array}$ & Std Error & $\begin{array}{r}\text { Partial } \\
\text { F-test }\end{array}$ \\
\hline VV & 15.11 & 0.0026 & 0.001 & 0.004 & 0.001 & 11.02 \\
\hline PUGG & 576.86 & 0.0003 & 0.000 & 0.000 & 0.000 & 4.21 \\
\hline RIVERKM & 61.99 & -0.0016 & -0.003 & -0.000 & 0.001 & 8.33 \\
\hline WEEKNO & 30.41 & 0.0043 & 0.000 & 0.008 & 0.002 & 4.21 \\
\hline Y-Intercept & 0.781 & & & & & \\
\hline \multicolumn{7}{|c|}{$\begin{array}{c}\text { LOG }(\text { DENSITY }) \\
\text { Correlation coefficient: } \mathrm{r}^{\wedge} 2=0.10\end{array}$} \\
\hline Variable & Mean & $\begin{array}{c}\text { B } \\
\text { coefficient }\end{array}$ & Lower & $\begin{array}{l}95 \% \text { confidence } \\
\text { Upper }\end{array}$ & Std Error & $\begin{array}{l}\text { Partial } \\
\text { F-test }\end{array}$ \\
\hline VV & 15.11 & 0.0053 & 0.000 & 0.010 & 0.002 & 4.84 \\
\hline WEEKNO & 30.41 & 0.0151 & 0.002 & 0.028 & 0.007 & 5.18 \\
\hline Y-Intercept & 2.718 & & & & & \\
\hline
\end{tabular}

Because the distributions of the data for each order exhibited a marked positive skewness, geometric means are presented here to give a more accurate picture of relative frequency than that provided by arithmetic means.

Statistically significant differences at the $95 \%$ level of confidence are noted for Diptera, Ephemeroptera, Bivalvia, Trichoptera, and Amphipoda. All are less frequent in the North Sydenham River. Other differences are either not statistically significant or indeterminate because of differences in variance. The low number of Gastropoda is attributable to the relative absence of both hard substrate and algal growths in the North Sydenham. The high number of Coleoptera (mainly Elmidae) relative to that in the St. Clair River is a salient feature probably attributable to the widespread presence of decomposing woody material (Dudley and Anderson 1982). Other factors probably contributing to the differences between the two river systems are the high sediment load of the water in the North Sydenham and the different temperature environment (Ward 1986; Hynes 1970).

TABLE 4. Yearly mean density of selected families. All sites combined.

\begin{tabular}{|c|c|c|c|c|}
\hline \multicolumn{5}{|c|}{ North Sydenham River (this study) } \\
\hline Year & Chironomidae & Gammaridae & Caenidae & Naididae \\
\hline 1996 & 1752 & 180 & 419 & 1709 \\
\hline 1997 & 2222 & 111 & 325 & 2538 \\
\hline 1998 & 2423 & 8 & 188 & 3256 \\
\hline 1999 & 1855 & 21 & 290 & 2440 \\
\hline 2000 & 1483 & 43 & 453 & 1487 \\
\hline \multicolumn{5}{|c|}{ St. Clair River (Harris 1999) } \\
\hline Year & Chironomidae & Gammaridae & Caenidae & Dreisseniidae \\
\hline 1990 & 436 & 483 & 13 & 0 \\
\hline 1991 & 1124 & 158 & 34 & 26 \\
\hline 1992 & 2226 & 103 & 205 & 103 \\
\hline 1993 & 4996 & 47 & 278 & 1038 \\
\hline 1994 & 4397 & 56 & 141 & 68 \\
\hline 1995 & 5607 & 51 & 77 & 8 \\
\hline
\end{tabular}




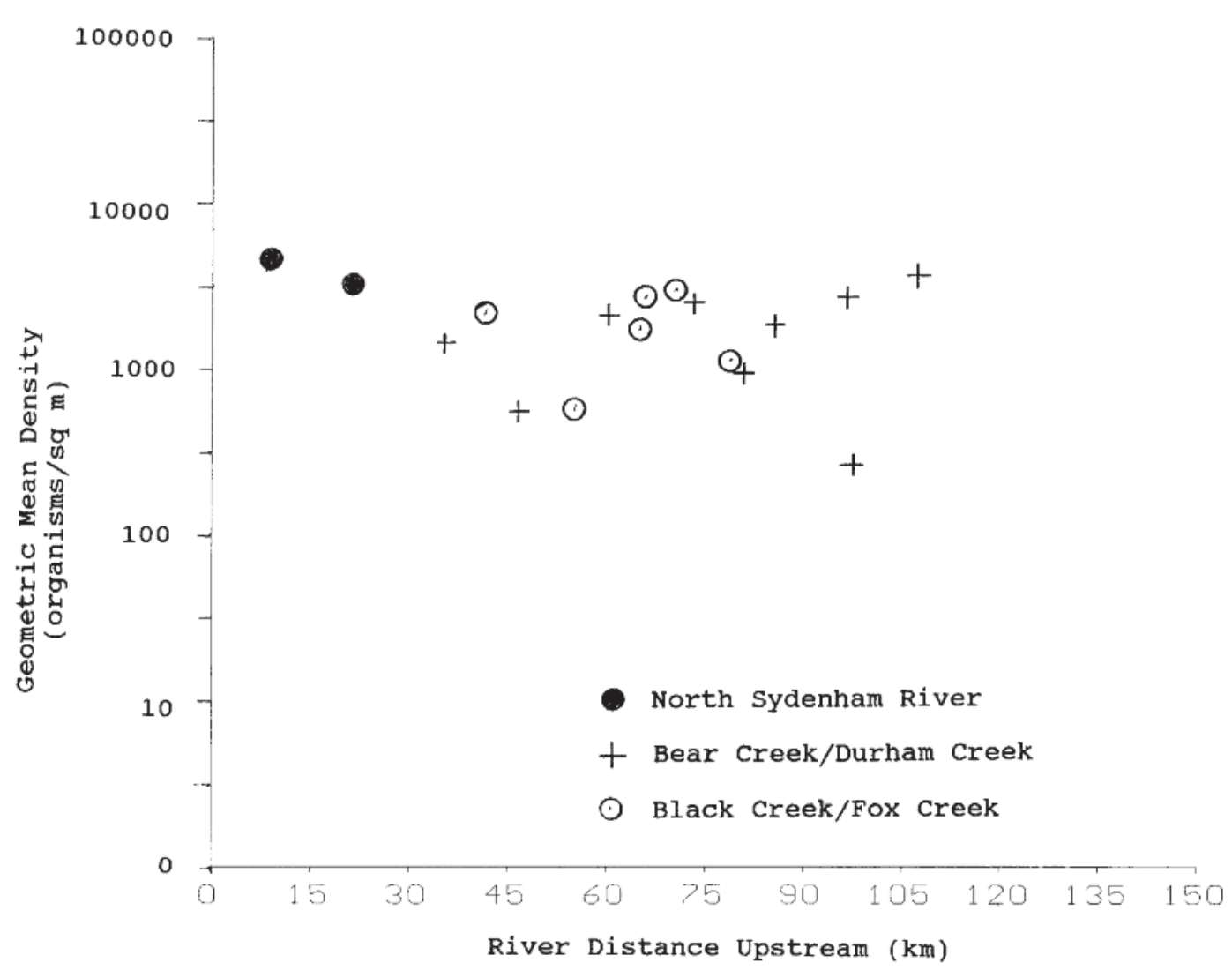

FIGURE 4. Geometric mean density (organisms $/ \mathrm{m}^{2}$ ) plotted against distance upstream $(\mathrm{km})$.

The same data are illustrated in Figure 5. Note that 10 orders have been added to the list to accommodate the different distribution of orders found in the North Sydenham than in the St. Clair River (Harris 1999). Note also that the use of geometric means instead of arithmetic means changes slightly the shape of the curve for the St. Clair downstream reach compared to that shown previously (Harris 1999).

In view of the studies of unionid populations in the Sydenham (Clarke 1992; Mackie 1988; VanDerWal $\left.2001^{*}\right)$, it is worth mentioning that in the grab sampling used in both the North Sydenham and St. Clair Rivers, no live unionid specimens were found; only one or two empty shells. All live Bivalvia found in the North Sydenham were Sphaeriidae although a few empty shells of Dreisseniidae were recovered at the sampling site farthest downstream (site 18). Both Sphaeriidae and Dreisseniidae were found in the St. Clair River (Harris 1999).

In general terms, the results of the comparison of the North Sydenham River with the downstream reach of the St. Clair River fit with the "River Continuum Concept" proposed by Vannote et al. (1980) and later elaborated by Minshall et al (1985). As would be expected, the more lentic environment of the North Sydenham supports fewer of the predator orders and more shredders. However, the heavy sediment load in the North Sydenham and the absence of a steady flow and vigorous wave action are complicating factors. A comparable study of a third order stream in a gravel bed and fed by glacial melt water carrying a heavy sediment load would be expected to support a population of invertebrates more similar to that in the downstream reach of the St. Clair River.

\section{Documents Cited (marked *)}

Chambers, Brian. 1997. Private communication documenting water quality data for the North Sydenham River in the period 1983-1994 gathered by the Ontario Ministry of the Environment, London, Ontario. 108 pages.

Frais, W. 2002. Private communication documenting suspended solids for the service water intake at the Bayer/ Nova plant downstream of Sarnia on the St. Clair River. 5 pages.

International Joint Commission. 1987. Great Lakes Water Quality Agreement of 1978 (amended 1987). 84 pages. [100 Ouellette Avenue, Windsor, Ontario, N9A 6T3.] 
TABLE 5. Relative abundance of individuals in invertebrate orders in the North Sydenham River system (1996-2000) and the downstream reach of the St. Clair River (1990-1995) (Harris 1999).

\begin{tabular}{|c|c|c|c|c|}
\hline \multirow[t]{2}{*}{ Organism } & \multicolumn{2}{|c|}{$\begin{array}{l}\text { North Sydenham River } \\
\text { (all sites) }\end{array}$} & \multicolumn{2}{|c|}{$\begin{array}{c}\text { St. Clair River } \\
\text { (downstream reach) }\end{array}$} \\
\hline & $\begin{array}{c}\text { Mean log } \\
\text { density }\end{array}$ & $\begin{array}{c}\text { Geom. mean } \\
\text { density* }\end{array}$ & $\begin{array}{c}\text { Mean log } \\
\text { density }\end{array}$ & $\begin{array}{c}\text { Geom. mean } \\
\text { density* }\end{array}$ \\
\hline Diptera ++ & 2.579 & 379 & 3.194 & 1565 \\
\hline Oligochaeta & 2.520 & 331 & 2.896 & 787 \\
\hline Gastropoda & 0.581 & 4 & 2.475 & 298 \\
\hline Ephemeroptera ++ & 1.708 & 51 & 2.167 & 147 \\
\hline Bivalvia ++ & 1.201 & 16 & 1.818 & 66 \\
\hline Trichoptera ++ & 0.639 & 4 & 1.672 & 47 \\
\hline Hydracarina & 0.210 & 2 & 1.454 & 28 \\
\hline Amphipoda ++ & 0.652 & 4 & 1.140 & 14 \\
\hline Nematoda & 0.434 & 3 & 0.877 & 8 \\
\hline Cladocera & 0.057 & 1 & 0.573 & 4 \\
\hline Turbellaria & 0.245 & 2 & 0.438 & 3 \\
\hline Coleoptera & 1.867 & 74 & 0.413 & 3 \\
\hline Ostracoda & 0.014 & 1 & 0.295 & 2 \\
\hline Isopoda & 0.163 & 2 & 0.138 & 1 \\
\hline Hemiptera & 0.710 & 5 & 0.124 & 1 \\
\hline Lepidoptera & 0.014 & 1 & 0.124 & 1 \\
\hline Megaloptera & 0.492 & 3 & 0.069 & 1 \\
\hline Hydroida & 0.032 & 1 & 0.055 & 1 \\
\hline Odonata & 0.215 & 2 & 0.055 & 1 \\
\hline Decapoda & 0.166 & 2 & 0.000 & 0 \\
\hline Hirudinea & 0.134 & 1 & 0.000 & 0 \\
\hline
\end{tabular}

* individual organisms $/ \mathrm{m}^{2}$

++ difference in geometric means is statistically significant at the $95 \%$ level of confidence; others are either not significant or are indeterminate because variances are significantly different

Kuley, E., and W. R. Brooks. 2001. Water Quality Assessment Program 2000 Annual Report. Prepared for the Sarnia-Lambton Environmental Association by Canadian ORTECH Environmental.

McDougall, Brian. 1998. Private communication documenting water flow data for 1993-1996 gathered by the St. Clair Region Conservation Authority, Strathroy, Ontario. 140 pages.

VanDerWal, J. J. 2001. The effect of turbidity on the freshwater mussels of the Sydenham River watershed, Ontario. MSc thesis, University of Western Ontario. 76 pages.

Jacques Whitford Environment Ltd. 2001. Report on the North Sydenham Recovery Project: synthesis and analysis of background data. 53 pages. (St. Clair Region Conservation Authority, Strathroy, Ontario).

\section{Literature Cited}

Clarke, A. H. 1992. Ontario's Sydenham River, an important refugium for native freshwater mussels against competition from the zebra mussel Dreissena polymorpha. Malacology Data Net, Volume 3, Numbers 1-4, 43-58.

Draper, N. R., and H. Smith. 1991. Applied Regression Analysis. John Wiley and Sons, New York, N. Y. 736 pages.

Dudley, T., and N. H. Anderson. 1982. A survey of invertebrates associated with wood debris in aquatic habitats. Melandria 39: 1-21.
Harris, I. W. E. 1999. Some factors affecting the density and richness of invertebrate populations in the near-shore sediments of the St. Clair River, 1990-1995. The Canadian Field-Naturalist 113(4): 576-584.

Hynes, H. B. N. 1970. The ecology of running waters. University of Toronto Press, Toronto, Ontario. 555 pages.

Mackie, G. L., and J. M. Topping. 1988. Historical changes in the unionid fauna of the Sydenham River watershed and downstream changes in shell morphometrics of three common species. Canadian Field-Naturalist 102: 617-626.

Merritt, R. W., and K. W. Cummins. 1988. An introduction to the aquatic insects of North America (2nd edition). Kendall/Hunt Publishing Co., Dubuque, Iowa. 722 pages.

Meyer, J. L. 1990. A blackwater perspective on riverine ecosystems. Bioscience 9: 643-651.

Minshall, G. W., K. W. Cummins, R. C. Petersen, C. E. Cushing, D. A. Bruns, J. R. Sedell, and R. L. Vannote. 1985. Developments in stream ecosystem theory. Canadian Journal of Fisheries and Aquatic Science 42: 1045-1055.

Pekarsky, B. L., P. R. Frassinet, M. A. Penton, and D. J. Conklin, Jr. 1990. Freshwater macroinvertebrates of northeastern North America. Cornell University Press, Ithaca, New York. 442 pages.

Pennak, R. 1989. Freshwater invertebrates of the United States (3rd edition). John Wiley and Sons, Toronto. 628 pages. 


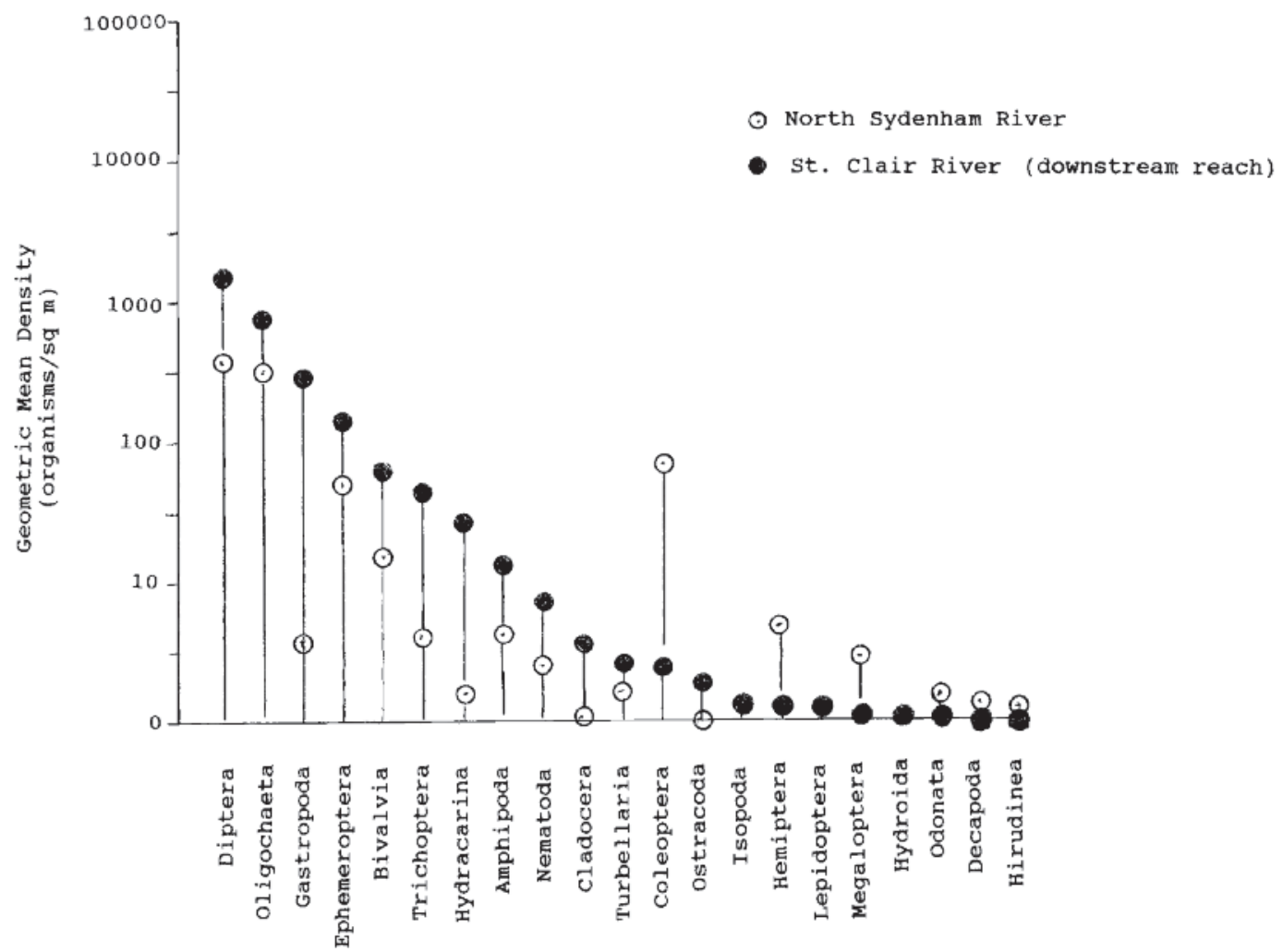

FIGURE 5. Relative abundance of invertebrate orders in the North Sydenham River (all sites combined) compared to the abundance of the same orders in the downstream reach of the St. Clair River (all sites combined).

Statzner, B., and B. Higler. 1986. Stream hydraulics as a major determinant of benthic invertebrate zonation patterns. Freshwater Biology 16: 127-139.

Thorp, J. H., and A. P. Covich. 1991. Ecology and classification of North American freshwater invertebrates. Academic Press Inc., Toronto. 911 pages.

Vannote, R. L., G. W. Minshall, K. W. Cummins, J. R. Sedell, and C. E. Cushing. 1980. The river continuum concept. Canadian Journal of Fisheries and Aquatic Science 37: 130-137.
Ward, J. V. 1986. Altitudinal zonation in a rocky mountain stream. Archiv fur Hydrobiologie, Supplement 74: 133-199.

Waters, T. F. 1972. The drift of stream insects. Annual Review of Entomology 17: 253-272.

Williams, D. D. 1981. Migrations and distribution of stream benthos. Perspectives in running water ecology. Plenum, New York. 430 pages.

Received 23 June 2002

Accepted 20 November 2003 